\title{
Infection due to Mycoplasma hominis after left hip replacement: case report and literature review
}

\author{
Lili Xiang ${ }^{1,2}$ and Binghuai $\mathrm{Lu}^{3,45^{*}}$ (D)
}

\begin{abstract}
Background: Hip replacement is generally conducted in those with prolonged arthritis pain or hip fractures, and postoperative infection is a serious complication. Mycoplasma hominis, belonging to mycoplasma species, exists mainly in the genitourinary tract. M. hominis infection after total hip replacement was rarely documented in literature.

Case presentation: A 59-year-old male was febrile after left total hip replacement. Empiric therapy with cefepime for suspected infection was ineffective. Specimens at the infection site were collected for culture, and pinpoint colonies grew after incubation at $35^{\circ} \mathrm{C}$ for $48 \mathrm{~h}$ on blood agar plate. They grew to approximately $0.5 \mathrm{~mm}$ colonies in diameter after 7-day incubation, and were identified as M. hominis. Sequentially, combination therapy with clindamycin hydrochloride and moxifloxacin was initiated, and the patient defervesced within 3 days and was discharged home.

Conclusions: The study highlighted the potential pathogenicity of $M$. hominis in postoperative infection. The possibility of this microorganism involvement should be valued if the patients who experienced the hip or joint replacement had inexplicable fever.
\end{abstract}

Keywords: Mycoplasma hominis, Postoperative infections, Hip replacement

\section{Background}

Mycoplasma hominis is a commensal bacterium of the urogenital tract and generally responsible for pelvic inflammatory illnesses and postpartum and neonatal infections [1-3]. M. hominis infections outside the genitourinary tract occurred rarely. However, to date, wound infection [4], meningitis [5], postoperative infections [6-9] and other disseminated infections in immunocompromised patients [10-12] due to the organism have been increasingly documented. Furthermore, hip replacement is commonly-conducted surgery to relieve obstinate arthritis pain or fractures in China. Herein, a case of extragenital infection caused by $M$. hominis after hip replacement was

\footnotetext{
* Correspondence: zs25041@126.com

${ }^{3}$ Laboratory of Clinical Microbiology and Infectious Diseases, Department of Pulmonary and Critical Care Medicine, China-Japan Friendship Hospital, Beijing, China

${ }^{4}$ Center for Respiratory Diseases, China-Japan Friendship Hospital, Beijing, China

Full list of author information is available at the end of the article
}

reported. Furthermore, we reviewed relevant literature to highlight the potential pathogenicity of $M$. hominis in postoperative infection.

\section{Case presentation Medical history}

A 59-year-old male was admitted to Chongqing Shapingba District Chenjiaqiao hospital, Chongqing, China. He suffered the fractures of left femoral neck after falling to the ground (Fig. 1a). On July 16, 2017, the left total hip replacement was conducted and prosthetic hip in position was shown under X-ray (Fig. 1b). Cefazolin sodium (1 g IV q8h) was started for prophylactic administration. His indwelling urinary catheter was removed after $24 \mathrm{~h}$. On the 8 th day after surgery, however, the patient presented with left hip pain and clinical signs of infection, including fever $\left(38.5^{\circ} \mathrm{C}\right)$, redness and swelling around the surgical site (Fig. 1c), and he also reported local tenderness. His blood examination demonstrated the white blood cell (WBC), C-reactive protein (CRP), 

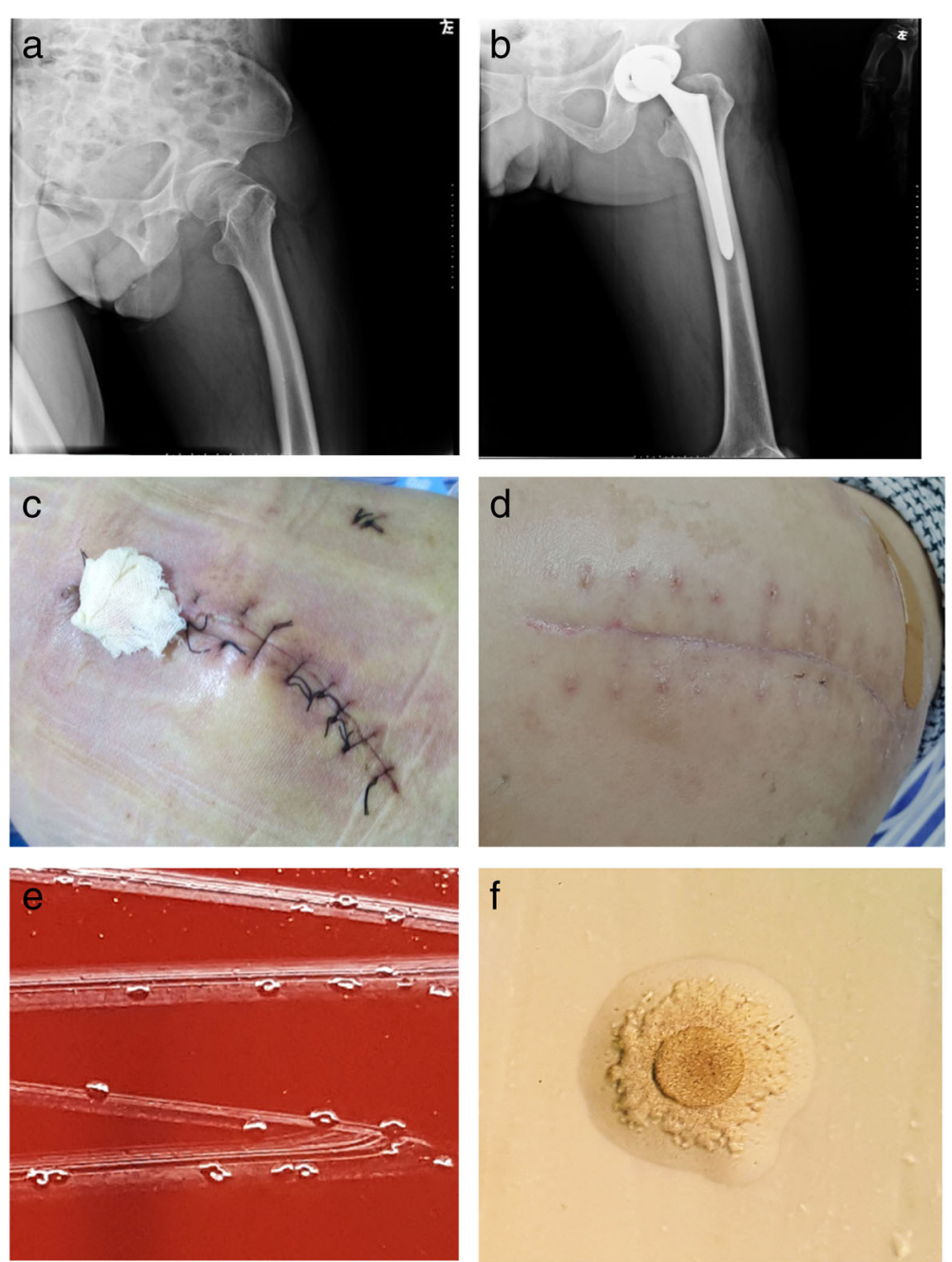

Fig. 1 a Fractures of left femoral neck under $X$-ray at admission. b Prosthetic hip in right position ( $2 \mathrm{~h}$ after hip replacement under $\mathrm{X}$-ray). c Redness and swelling around surgical site, wound fluctuation in palpation (8 days after surgery). $\mathbf{d}$ Recovered after anti- M. hominis treatment with the combination of moxifloxacin, and doxycycline (18 days after surgery). e After 7 day of incubation of subcutaneous fluid collected during debridement on blood agar at $37^{\circ} \mathrm{C}$ in a $5 \% \mathrm{CO}_{2}$ atmosphere, tiny, nonhemolytic, transparent colonies grew on Columbia blood agar plate. $\mathbf{f}$ Fried-egg-type colonies of Mycoplasma hominis on solid media 5 days after subculture

and erythrocyte sedimentation rate (ESR) significantly increased during postoperative period, as shown in Fig. 2. Furthermore, the screening tests for human immunodeficiency virus, hepatitis $B$ virus and hepatitis $C$ virus infections were non-reactive, and no abnormality in liver or renal function tests was observed. His T-lymphocyte subsets and gamma-globulin analysis were within normal range.

On July 25, 2017, approximately 400-ml light-yellow, odorless subcutaneous fluid was punctured at surgical site, and forwarded to the microbiological laboratory for bacterial smear and culture. A large amount of polymorphonuclear leucocytes (PMNs) were detected but no microorganism on gram-staining smear. Moreover, there was a negative growth on the blood and chocolate agar plates. The repeated blood cultures using the BacT/ALERT
3D blood culture microbial detection system (bioMérieux SA, Marcy l'Étoile, France) were negative. The post-surgical infection was still under suspicion, and the wound was cleaned with iodophor and drainage gauze was placed. Cefepime (2 g IV q12h) was administrated. However, empiric therapy was still ineffective, the prosthetic hip infection deteriorated, fever persisted, and on July 26 , the debridement of left prosthetic hip was performed and the seroma, superficial fascia, deep fascia, deep tissue, as well as subcutaneous fluid collected during the surgery were sent for culture on blood and chocolate agar plates. Unexpectedly, tiny colonies grew after $48 \mathrm{~h}$, and they grew to approximately 0.5 $\mathrm{mm}$ colonies in diameter after 7-day incubation (Fig. 1e), and were identified as $M$. hominis by the bioMérieux ${ }^{\circ}$ SA Mycoplasma IST2 kit (bioMérieux, France). The identification was also confirmed with $16 \mathrm{~S}$ rRNA sequencing. 


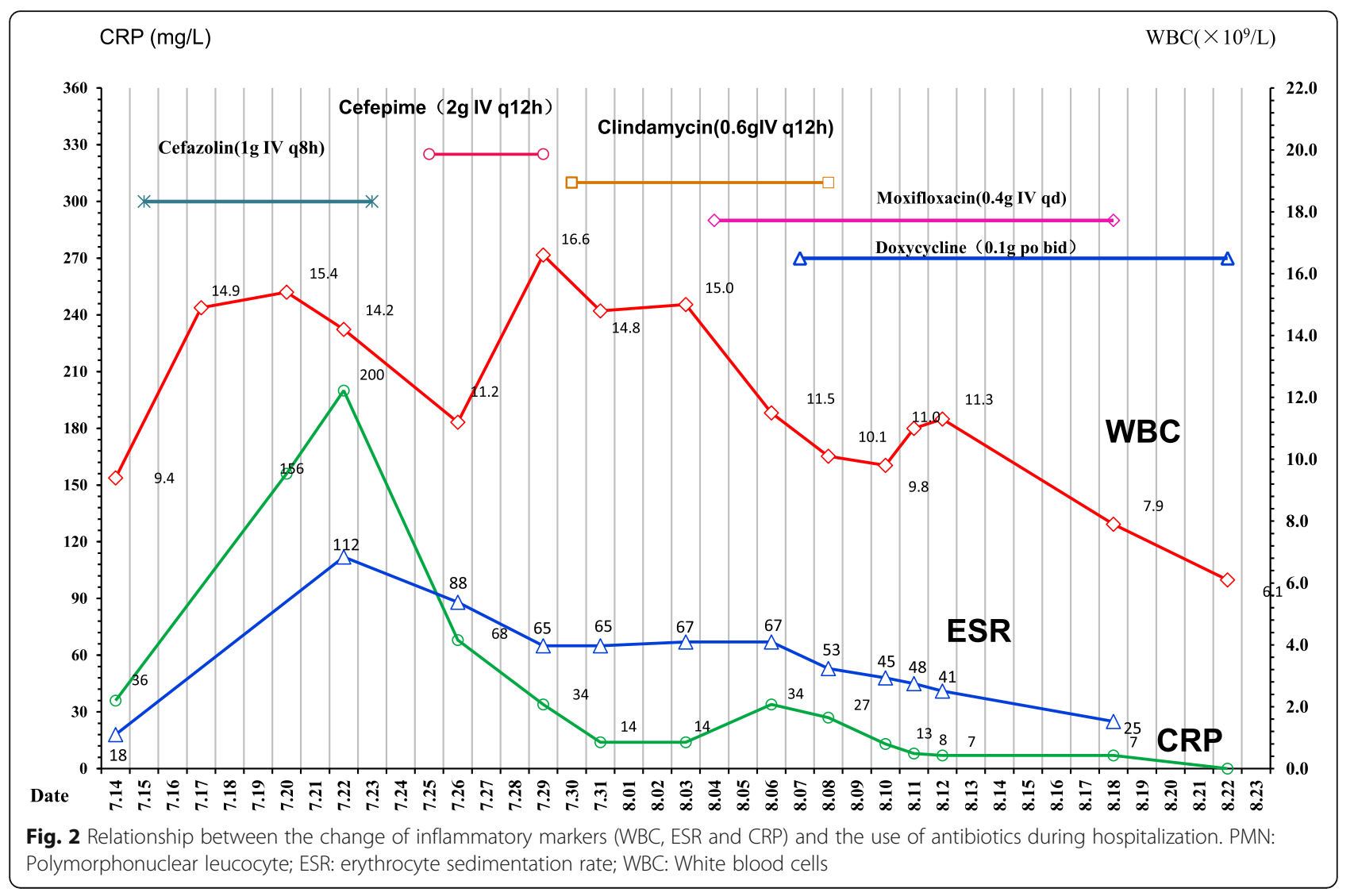

In vitro antimicrobial susceptibility testing (AST) revealed that the organism was susceptible to doxycycline, clindamycin and levofloxacin, but resistant to azithromycin by the bioMérieux ${ }^{\circ}$ SA Mycoplasma IST2 kit (Biomerieux, France). Combination therapy with clindamycin hydrochloride ( $0.6 \mathrm{~g}$ IV q12h) and moxifloxacin (400 mg IV QD) was initiated, as shown in Fig. 2. The patient defervesced within 3 days. His infection site recovered gradually (Fig. 1d). Repeated X-ray scans before discharge showed marked improvement of his prosthetic hip. The patient was discharged on August 23, without further complications. No recurrence of symptoms and signs was reported during three-month outpatient follow-up.

\section{Microbiological test}

After $48 \mathrm{~h}$ of incubation on blood agar at $37{ }^{\circ} \mathrm{C}$ in a $5 \%$ $\mathrm{CO}_{2}$ atmosphere, pinpoint-sized, non-hemolytic, and transparent colonies were found on Columbia blood agar plate. The colonies were difficult to emulsify in saline water during the preparation of suspension solution for identification and AST. Both Gram stain and Wright-Giemsa mixed stain of the isolates demonstrated no bacterial morphology under $\times 1000$ magnification, and only granular aggregates were detected. Fried-egg-type colonies of $M$. hominis growed on solid media (Zhongqisheng Hebei Bio-tech Co., Ltd.) 5 days after subculture (Fig. 1f).

\section{Discussion and conclusions}

$M$. hominis is part of the normal inhabitant of the genitourinary tract [6]. However, in line with publicly-available documents, it might disseminate to other body sites secondary to a disruption of the mucosa or in patients with autoimmune disorders, hypogammaglobulinemia, and other underlying immunosuppressions [3, 12-15]. Herein, we described the clinical circumstances, treatment, and outcomes of a postoperative septic complication due to the microorganism after hip replacement. To the best of our knowledge, this is the first report of $M$. hominis as the causative, fastidious agent of prosthetic hip infection in China.

To better understand the characteristics of postoperative infection after hip or knee replacement, PubMed was searched for literature review and 5 cases by $M$. hominis in 4 reports were included for comparison (Table 1) [16-19]. The literature review demonstrated that, including our case, the gender ratio of male/female suffered $M$. hominis infection after joint or tip replacement was 5:1. The median age was 64 years old. Furthermore, as documented, CRP concentrations were available in 4 out of 5 cases, and all their CRP levels were higher than $100 \mathrm{mg} / \mathrm{L}$. Our case also had an increased CRP $(200 \mathrm{mg} / \mathrm{L})$, hinting elevated CRP level would help in suspecting postoperative $M$. hominis infection. The review also described that the most common and 
Table 1 Summary of the reported cases of Mycoplasma hominis after joint or hip replacement

\begin{tabular}{|c|c|c|c|c|c|c|}
\hline & $1[16]$ & $2[17]$ & $3[17]$ & 4 [18] & 5 [19] & 6 current case \\
\hline Case Number & 1 & 1 & 1 & 1 & 1 & 1 \\
\hline Age (years) & 62 & 71 & 76 & 66 & 54 & 59 \\
\hline Surgery & $\begin{array}{l}\text { Left total knee } \\
\text { replacement } \\
\text { due to knee } \\
\text { osteoarthritis. }\end{array}$ & $\begin{array}{l}\text { Left total knee } \\
\text { replacement. }\end{array}$ & $\begin{array}{l}\text { Left knee joint } \\
\text { replacement. }\end{array}$ & $\begin{array}{l}\text { Bilateral total knee } \\
\text { replacements } 5 \\
\text { years ago and a } \\
\text { left total hip } \\
\text { replacement } 2 \\
\text { years ago. }\end{array}$ & $\begin{array}{l}\text { Implantation } \\
\text { of a total hip } \\
\text { prosthesis one } \\
\text { month before. }\end{array}$ & $\begin{array}{l}\text { Left hip } \\
\text { replacement. }\end{array}$ \\
\hline Gender & Male & Male & Male & Female & Male & Male \\
\hline Fever & Yes & $39.7^{\circ} \mathrm{C}$ & $38.7^{\circ} \mathrm{C}$ & Yes & Yes & $38.5^{\circ} \mathrm{C}$ \\
\hline \multicolumn{7}{|c|}{ Infection indicators } \\
\hline $\mathrm{CRP}(\mathrm{mg} / \mathrm{L})$ & 208.3 & 122.4 & 143.6 & NA & 374 & 200 \\
\hline $\operatorname{WBC}\left(\times 10^{9} / \mathrm{L}\right)$ & NA & $\begin{array}{l}10.25 \text { (Neutrophils } \\
81.4 \% \text { ) }\end{array}$ & $\begin{array}{l}11.83 \text { (Neutrophils } \\
88.3 \% \text { ) }\end{array}$ & 6.0 & 6.9 & 15.4 \\
\hline $\mathrm{ESR}(\mathrm{mm} / \mathrm{hr})$ & NA & 61 & 63 & 101 & NA & 112 \\
\hline $\begin{array}{l}\text { Microbiological } \\
\text { test results }\end{array}$ & $\begin{array}{l}\text { Bacterial and fungi } \\
\text { culture of wound } \\
\text { exudation and } \\
\text { seepage } \\
\text { demonstrated a } \\
\text { negative growth, } \\
\text { whereas the } \\
\text { secretion collected in } \\
\text { the operation } \\
\text { suggested a } \\
\text { positive } M \text {. } \\
\text { hominis growth, } \\
\text { identified by mass } \\
\text { spectrometer. }\end{array}$ & $\begin{array}{l}\text { Pinpoint, } \\
\text { translucent } \\
\text { colonies on } \\
\text { Brucella agar after } \\
\text { 2-day incubation } \\
\text { of joint fluid, } \\
\text { confirmed as } \mathrm{M} \text {. } \\
\text { hominis by } 16 \mathrm{~S} \\
\text { rRNA sequencing. }\end{array}$ & $\begin{array}{l}\text { Anaerobic culture } \\
\text { for } 3 \text { days } \\
\text { incubation of joint } \\
\text { fluid indicated the } \\
\text { growth of } M \text {. } \\
\text { hominis. }\end{array}$ & $\begin{array}{l}\text { Cultures of the } \\
\text { aspiration fluid of } \\
\text { the knee revealed } \\
\text { very small clear } \\
\text { colonies were } \\
\text { seen on the blood } \\
\text { agar plates, } \\
\text { present on both } \\
\text { the aerobic and } \\
\text { anaerobic plates. }\end{array}$ & $\begin{array}{l}\text { At the time of } \\
\text { admission, Gram } \\
\text { stain of a swab } \\
\text { taken from the } \\
\text { wound of the } \\
\text { right hip showed } \\
\text { rare leukocytes } \\
\text { but no bacteria, } \\
\text { and cultures were } \\
\text { negative. Cultures } \\
\text { of the effusion } \\
\text { collected via } \\
\text { arthroscopy of the } \\
\text { left knee } \\
\text { remained } \\
\text { negative. The } \\
\text { biopsy of the } \\
\text { inflamed tissue } \\
\text { revealed no } \\
\text { bacteria on Gram } \\
\text { staining, and no } \\
\text { growth after } 14- \\
\text { day culture. M. } \\
\text { hominis. Was iden } \\
\text { tified via16S rRNA } \\
\text { sequencing. }\end{array}$ & $\begin{array}{l}\text { After } 48 \mathrm{~h} \text { of } \\
\text { incubation on } \\
\text { blood agar at } \\
37^{\circ} \mathrm{C} \text { in a } 5 \% \mathrm{CO}_{2} \\
\text { atmosphere, tiny, } \\
\text { non-hemolytic, } \\
\text { transparent } \\
\text { colonies were } \\
\text { found on } \\
\text { Columbia blood } \\
\text { agar plates. }\end{array}$ \\
\hline $\begin{array}{l}\text { Presentation of } \\
\text { post-surgical } \\
\text { infection }\end{array}$ & $\begin{array}{l}\text { Blood seeping } \\
\text { and pale clear } \\
\text { liquid exudation } \\
\text { from the wound } \\
\text { were observed on } \\
\text { the } 3 r d \text { and } 4 \text { th } \\
\text { day after the } \\
\text { surgery. }\end{array}$ & $\begin{array}{l}\text { Three days after } \\
\text { operation, there } \\
\text { were redness and } \\
\text { swelling, pain at } \\
\text { surgical site. }\end{array}$ & $\begin{array}{l}\text { One day after } \\
\text { operation, fever, } \\
\text { redness and } \\
\text { swelling around } \\
\text { knee were } \\
\text { observed. }\end{array}$ & NA & $\begin{array}{l}\text { Implantation of } \\
\text { a total hip } \\
\text { prosthesis one } \\
\text { month before. } \\
\text { Symptoms of a } \\
\text { septic arthritis in } \\
\text { both knees and } \\
\text { hips and delayed } \\
\text { wound healing } \\
\text { and fistula } \\
\text { formation after } \\
\text { implantation } \\
\text { of a total hip } \\
\text { prosthesis one } \\
\text { month before. }\end{array}$ & $\begin{array}{l}\text { Eight day after } \\
\text { surgery, the } \\
\text { patients presented } \\
\text { with left hip pain } \\
\text { and clinical signs } \\
\text { of infection, } \\
\text { including fever } \\
\left(38.5^{\circ} \mathrm{C}\right) \text {, redness } \\
\text { and swelling } \\
\text { around the } \\
\text { surgical site. And } \\
\text { he reported } \\
\text { significant local } \\
\text { press pain. } \\
\text { Approximately } \\
400-m l \text { light yel } \\
\text { low, odorless } \\
\text { effusion of the } \\
\text { wound was drained. }\end{array}$ \\
\hline
\end{tabular}


Table 1 Summary of the reported cases of Mycoplasma hominis after joint or hip replacement (Continued)

\begin{tabular}{|c|c|c|c|c|c|c|}
\hline & $1[16]$ & $2[17]$ & $3[17]$ & $4[18]$ & $5[19]$ & 6 current case \\
\hline $\begin{array}{l}\text { Antibiotic } \\
\text { prevention }\end{array}$ & Cefazolin & $\begin{array}{l}\text { Ceftazidime, } \\
\text { vancomycin }\end{array}$ & Vancomycin & NA & NA & Cefazolin \\
\hline $\begin{array}{l}\text { Antibiotic } \\
\text { treatment. }\end{array}$ & $\begin{array}{l}\text { Cefazolin was } \\
\text { replaced by } \\
\text { vancomycin. Later } \\
\text { transferred to the } \\
\text { combination into } \\
\text { erythromycin, } \\
\text { clindamycin and } \\
\text { minocyline. }\end{array}$ & $\begin{array}{l}\text { Vancomycin, } \\
\text { metronidazole. }\end{array}$ & $\begin{array}{l}\text { Vancomycin. Later } \\
\text { switched to } \\
\text { azithromycin, } \\
\text { doxycycline, } \\
\text { moxifloxacin. }\end{array}$ & $\begin{array}{l}\text { Cefazolin } 500 \mathrm{mg} \\
\text { of tetracycline iv } \\
\text { every } 8 \mathrm{~h} \text {. After } \\
\text { the first week, } \\
\text { switched to oral } \\
\text { doxycycline ( } 200 \\
\text { mg/day), and over } \\
\text { the next } 3 \text { weeks. }\end{array}$ & $\begin{array}{l}\text { Ciprofloxacin and } \\
\text { clindamycin; } \\
\text { subsequently } \\
\text { changed to } \\
\text { cefazolin and } \\
\text { clindamycin, } \\
\text { continued for } 4 \\
\text { weeks; and later } \\
\text { changed to } \\
\text { moxifloxacin and } \\
\text { rifampin for a } \\
\text { presumed chronic } \\
\text { S. epidermidis } \\
\text { infection. } \\
\text { Treatment with } \\
\text { moxifloxacin was } \\
\text { initiated, however } \\
\text { the patient's } \\
\text { condition } \\
\text { continued to } \\
\text { deteriorate. }\end{array}$ & $\begin{array}{l}\text { Cefepime, } \\
\text { clindamycin, } \\
\text { moxifloxacin, } \\
\text { and doxycycline. }\end{array}$ \\
\hline Blood culture & Negative & Negative & Negative & Negative & Negative & Negative \\
\hline Outcome & Recovery & Recovery & Recovery & Recovery & Dead & Recovery \\
\hline
\end{tabular}

WBC white blood cell, CSF cerebrospinal fluid, $N$ negative, NA not available, $w$ week, $y$ year

effective test for diagnosing joint or hip M. hominis infection was the culture of wound exudation, joint fluid, and aspiration fluid of the knee [16-19]. In our case, M. hominis was recovered from subcutaneous puncture fluid and successfully identified. This showed that, if the tiny colonies grew on the blood agar plate without obvious bacteria shapes under gram-staining smears, $M$. hominis should be suspected of being underlying pathogen $[16,17]$. Presently, the molecular methods, such as $16 \mathrm{~S}$ rRNA sequencing or real-time PCR, might be used for the identification of infections caused by the bacterium $[17,19]$.

Furthermore, it is difficult to clarify the possible portal of entry of $M$. hominis in cases of this postoperative infection [20]. In accordance with previous reports, the source for an M. hominis in postoperative hip or joint infections might be explained by seeding of surgical site through transient bacteraemia. This bloodstream infection occurred after urinary catheterization if the genitourinary tract had been colonized by the microorganism. Indeed, urinary tract catheterization has been associated with mycoplasma bacteraemia leading to the seeding of brain-damaged tissues in brain abscess cases [5, 6, 9, 21]. Similarly, in our case, a possible pathway might be indwelling catheter used during surgery and a possible route for hematogenous spread to surgical site. However, it is rather difficult to definitively identify the source of infection.

It presented a challenge to identify $M$. hominis as pathogen due to its elusiveness and fastidious slow-growing nature $[5,8,13,22,23]$. This might be explained by the following reasons. Firstly, $M$. hominis has a 3-layer sterol membrane but lacks cell wall. Consequently, the inability to detect Mycoplasma spp. by routine gram-staining contributes to the failure of detection in the clinical specimens [24]. In present case, the gram-staining and Wright-Giemsa mixed staining smear of subcutaneous fluid and the colonies demonstrated no bacterial morphology. Secondly, the slow-growth properties of $M$. hominis made the detection on plates challenging, because it generally takes several days (often $\geq 2$ days) to grow into tiny colonies on the media commonly used in laboratory and the requirement for extended incubation period makes a timely diagnosis less likely. And moreover, the routine biochemical methods might fail to identify it correctly [18]. Thirdly, it is rather difficult to detect the growth of $M$. hominis in standard blood culture bottle solutions that use polyanethol sulfonate as an anticoagulant but rather requiring special methods for growth through automatic detection systems in those with suspected bacteremia, and false-negative results are likely yielded [16-19, 24]. Taken together, the post-surgical $M$. hominis infection cases are not readily detected via standard microbiology methods [7, 19]. Considering the high urethral carriage rate of $M$. hominis $(\sim 15 \%$ of healthy adults) and catheterization is a common procedure during operation, the possibility of postoperative Mycoplasma infection might be under-diagnosed or reported [8]. 
Our Pubmed review showed that 83.3\% (5/6) of the patients survived after appropriate antimicrobial treatment. Furthermore, previous studies demonstrated that the mycoplasmas resulted in serious infections without timely detection $[15,19,22]$. For example, a patient with implantation of a total hip prosthesis died due to a postoperative hip prosthesis and disseminated infection by M. hominis and Ureaplasma parvum [19]. Accordingly, if a patient developed unexplained post-surgical fever in cases of otherwise culture-negative infections, particularly if treat with wide-spectrum antibiotics meets with a poor response, it is especially important to consider the potential of Mycoplasmas as pathogens.

Empiric therapy for postoperative infections generally includes agents such as beta-lactams and vancomycin that act on the bacterial cell wall. Such an initial therapy will show no efficacy against $M$. hominis infections due to its lack of cell wall $[16,17]$. Furthermore, $M$. hominis is, in contrast to most mycoplasmas, intrinsically resistant to currently available macrolide antibiotics due to the mutations in the 23S rRNA gene and is the only mycoplasma susceptible to clindamycin, which often used for eradicating $M$. hominis with favorable results [16]. Quinolones (ciprofloxacin or moxifloxacin) or tetracyclines (minocyline) are active against $M$. hominis and moxifloxacin appears to have the greatest activity as the most effective therapeutic agent. If $M$. hominis was correctly identified as underlying pathogen, the antibiotics would be therefore switched to the right agents with a marked improvement of clinical syndromes and a favorable result $[16,19]$. The patient in our case had the regimen of the combination of moxifloxacin and doxycycline and had positive response.

In summary, the postoperative infection after hip replacement secondary to $M$. hominis is rare. Currently there are 4 published reports of septic arthritis caused by $M$. hominis after hip or knee replacement in adults. Our case added to this body of evidence. The clinicians should recognize the possibility of $M$. hominis involvement in postoperative infections without microbiological findings or response to standard therapy, and consider changing antibiotic regimen.

\section{Abbreviations}

CRP: C-reactive protein (CRP); ESR: Erythrocyte sedimentation rate; WBC: White blood cell

\section{Acknowledgements}

Not applicable.

\section{Funding}

This study was supported by Beijing Municipal Science \&Technology Commission, PR China (No. Z171100001017118). The funding bodies had no role in the design of the study and collection, analysis, and interpretation of data and in writing the manuscript.
Availability of data and materials

All the data and material involved in the current study are available from the corresponding author on reasonable request.

\section{Authors' contributions}

$\mathrm{BHL}$ was involved in the conception and design of the study, and writing, review and editing of the manuscript. LLX was involved in the data acquisition and analysis, and collected clinical data. Both authors read and approved the final manuscript

\section{Ethics approval and consent to participate}

The institutional review boards at the Chongqing Shapingba District Chenjiaqiao hospital approved the study protocol.

\section{Consent for publication}

Written informed consent was obtained from the patient for publication of this case report and any accompanying images. A copy of the written consent is available for review by the editor of this journal.

\section{Competing interests}

The authors declare that they have no competing interests.

\section{Publisher's Note}

Springer Nature remains neutral with regard to jurisdictional claims in published maps and institutional affiliations.

\section{Author details}

'Department of Laboratory Medicine, Chongqing Shapingba District Chenjiaqiao hospital, Chongqing, China. ${ }^{2}$ Affiliated Hospital of Chongqing Medical and Pharmaceutical College, Chongqing, China. ${ }^{3}$ Laboratory of Clinical Microbiology and Infectious Diseases, Department of Pulmonary and Critical Care Medicine, China-Japan Friendship Hospital, Beijing, China.

${ }^{4}$ Center for Respiratory Diseases, China-Japan Friendship Hospital, Beijing, China. ${ }^{5}$ National Clinical Research Center of Respiratory Diseases, Beijing, China.

Received: 2 March 2018 Accepted: 7 January 2019

Published online: 14 January 2019

\section{References}

1. Allen-Daniels MJ, Serrano MG, Pflugner LP, Fettweis JM, Prestosa MA, Koparde VN, Brooks JP, Strauss JF 3rd, Romero R, Chaiworapongsa T, et al. Identification of a gene in Mycoplasma hominis associated with preterm birth and microbial burden in intraamniotic infection. Am J Obstet Gynecol. 2015;212(6):779 e771-779 e713.

2. Flouzat-Lachaniette $\mathrm{CH}$, Guidon J, Allain J, Poignard A. An uncommon case of mycoplasma hominis infection after total disc replacement. Eur Spine J. 2013;22(Suppl 3):S394-8

3. Phuah $\mathrm{CL}$, Javid $\mathrm{B}$, Aliyu $\mathrm{SH}$, Lever AM. A case of mycoplasma hominis septic arthritis postpartum. J Infect. 2007;55(5):e135-7.

4. Krijnen MR, Hekker T, Algra J, Wuisman PI, Van Royen BJ. Mycoplasma hominis deep wound infection after neuromuscular scoliosis surgery: the use of real-time polymerase chain reaction (PCR). Eur Spine J. 2006;15(Suppl 5):599-603.

5. Zhou M, Wang P, Chen S, Du B, Du J, Wang F, Xiao M, Kong F, Xu Y. Meningitis in a Chinese adult patient caused by mycoplasma hominis: a rare infection and literature review. BMC Infect Dis. 2016;16(1):557.

6. Whitson WJ, Ball PA, Lollis SS, Balkman JD, Bauer DF. Postoperative mycoplasma hominis infections after neurosurgical intervention. J Neurosurg Pediatr. 2014;14(2):212-8.

7. Yokoyama H, Domen T, Hiragata S, Ogawa T, Matsumoto T, Ishizuka O. Postoperative mycoplasma hominis infection after robot-assisted laparoscopic radical prostatectomy: a case report. Asian J Endosc Surg. 2016; $9(2): 146-8$.

8. Bergin SM, Mendis SM, Young B, Binti Izharuddin E. Postoperative mycoplasma hominis brain abscess: keep it in mind!. BMJ Case Rep. 2017; 2017:1-3.

9. Le Guern R, Loiez C, Loobuyck V, Rousse N, Courcol R, Wallet F. A new case of mycoplasma hominis mediastinitis and sternal osteitis after cardiac surgery. Int J Infect Dis. 2015;31:53-5. 
10. Meyer RD, Clough W. Extragenital mycoplasma hominis infections in adults: emphasis on immunosuppression. Clin Infect Dis. 1993;17(Suppl 1):S243-9.

11. Miranda C, Camacho E, Reina G, Turino J, Rodriguez-Granger J, Yeste R, Bautista MF, Garcia M, Alados JC, De la Rosa M. Isolation of mycoplasma hominis from extragenital cultures. Eur J Clin Microbiol Infect Dis. 2005;24(5): 334-7.

12. Fernandez S, Nicolas D, Pericas JM, Castro Rebollo P, Vila J, Miro JM, Blanco $J$, Nicolas JM. A case of Mycoplasma hominis disseminated infection in a human immunodeficiency virus-1-infected pregnant woman with hypogammaglobulinemia. J Microbiol Immunol Infect. 2017;50(1):118-9.

13. Romeu Prieto JM, Lizcano Lizcano AM, Lopez de Toro Martin Consuegra I, Largo Pau J, Lopez Almodovar LF, Garcia Camacho E. Culture-negative endocarditis: mycoplasma hominis infection. Rev Esp Cardiol. 2015;68(11): $1037-8$.

14. Lee EH, Winter HL, van Dijl JM, Metzemaekers JD, Arends JP. Diagnosis and antimicrobial therapy of mycoplasma hominis meningitis in adults. Int J Med Microbiol. 2012;302(7-8):289-92.

15. Wylam ME, Kennedy CC, Hernandez NM, Peters SG, Maleszewski JJ, Cassivi SD, Scott JP. Fatal hyperammonaemia caused by mycoplasma hominis. Lancet. 2013;382(9908):1956.

16. Qiu HJ, Lu WP, Li M, Wang ZM, Du QY, Wang AM, Xiong Y. The infection of Mycoplasma hominis after total knee replacement: Case report and literature review. Chin J Traumatol. 2017;20(4):243-5.

17. Lee JH, Lee JH, Lee NY, Ha CW, Chung DR, Peck KR. Two cases of septic arthritis by mycoplasma hominis after total knee replacement arthroplasty. Korean J Lab Med. 2009;29(2):135-9.

18. Sneller M, Wellborne F, Barile MF, Plotz P. Prosthetic joint infection with mycoplasma hominis. J Infect Dis. 1986;153(1):174-5.

19. MacKenzie CR, Nischik N, Kram R, Krauspe R, Jager M, Henrich B. Fatal outcome of a disseminated dual infection with drug-resistant mycoplasma hominis and Ureaplasma parvum originating from a septic arthritis in an immunocompromised patient. Int J Infect Dis. 2010;14(Suppl 3):e307-9.

20. Pailhories H, Rabier V, Eveillard M, Mahaza C, Joly-Guillou ML, Chennebault $J M$, Kempf M, Lemarie C. A case report of mycoplasma hominis brain abscess identified by MALDI-TOF mass spectrometry. Int J Infect Dis. 2014; 29:166-8.

21. Cuchý E, Cherta I, Garau J. Mycoplasma hominis catheter-related infection in a patient with multiple trauma. Clin Microbiol Infect. 2000;6(2):115-6.

22. Reissier S, Masson R, Guerin F, Viquesnel G, Petitjean-Lecherbonnier J, Pereyre S, Cattoir V, Isnard C. Fatal nosocomial meningitis caused by mycoplasma hominis in an adult patient: case report and review of the literature. Int J Infect Dis. 2016;48:81-3.

23. Koshiba H, Koshiba A, Daimon Y, Noguchi T, Iwasaku K, Kitawaki J. Hematoma and abscess formation caused by mycoplasma hominis following cesarean section. Int J Women's Health. 2011;3:15-8.

24. Tyner HL, Virk A, Nassr A, Razonable R. Mycoplasma hominis vertebral spine infection: case report and a review of infections of bone and joints. J Infect Chemother. 2016;22(11):755-8.

Ready to submit your research? Choose BMC and benefit from:

- fast, convenient online submission

- thorough peer review by experienced researchers in your field

- rapid publication on acceptance

- support for research data, including large and complex data types

- gold Open Access which fosters wider collaboration and increased citations

- maximum visibility for your research: over $100 \mathrm{M}$ website views per year

At $\mathrm{BMC}$, research is always in progress.

Learn more biomedcentral.com/submissions 